\title{
Youth leadership: A proposal for identifying and developing creativity and giftedness
}

\author{
Liderança em jovens: uma proposta para \\ identificação e desenvolvimento da \\ criatividade e superdotação
}

\author{
Steven I. PFEIFFER \\ Solange Muglia WECHSLER ${ }^{2}$
}

\begin{abstract}
There is a considerable amount of literature on leadership, particularly as it relates to organizations, government, and the military. However, educators and psychologists know considerably less about early precursors of leadership, how leadership develops in youth, possible gender differences, and the relationship of leadership, intelligence and creativity. A global consensus exists that leaders are needed and that we shouldn't delay the early development of leadership skills. The authors propose a model to enhance creative leadership and introduce a teacher-completed rating scale, the Gifted Rating Scales to help accomplish this. As demonstrated, there are possibilities to detect early creative and intellectual giftedness among children and youngsters in the classrooms and expectations to move from a basic level of competence to reach an elite or expert level in any field, facilitating the emergence of leadership.
\end{abstract}

Uniterms: Creativity; Giftedness; High ability; Intelligence; Leadership.

\section{Resumo}

O tema da liderança vem sendo debatido intensamente na literatura, principalmente no ambiente empresarial, governamental e militar. Entretanto, o conhecimento é bastante escasso entre os educadores e psicólogos sobre os indicadores da liderança, ou melhor, como a liderança se desenvolve entre os jovens, possíveis diferenças de sexo, e a relação da inteligência com a criatividade. Os autores apresentam um modelo para estimular a liderança criativa assim como uma escala para professores avaliarem superdotação a fim de atingir este objetivo. Como demonstrado, existem possibilidades de detectar a superdotação intelectual e criativa entre crianças ejovens e expectativas de superação de um nível básico de competência para atingir o de especialista ou esperto, em qualquer área, permitindo assim o aparecimento da liderança.

Unitermos: Criatividade; Superdotação; Altahabilidade; Inteligência; Liderança.

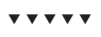

1 Florida State University, College of Education. 1114 W. Call Street, STB - 306-H, 32306, Tallahassee, FL, USA. Correspondência paral Correspondence to: S.I. PFEIFFER. E-mail: <spfeiffer@fsu.edu>.

2 Pontifícia Universidade Católica de Campinas, Centro de Ciências da Vida, Programa de Pós-Graduação em Psicologia. Campinas, SP, Brasil. 


\section{Youth leadership: Relationship to giftedness and creativity}

Over 10,000 books and articles in the English language have been written on leadership. Very likely many hundreds of books and articles in Portuguese have been written on this topic, as well. We know a great deal about leaders, particularly when related to organizations, government, and the military. However, educators and psychologists know considerably less about early precursors of leadership, how it develops in youth, and its relationship to intelligence. In fact, it is unclear whether leadership is best viewed as an aptitude or ability, as a set of interpersonal skills, a personality style, or some combination (Pfeiffer, 2001; 2012a).

In the United States (US) a number of youth organizations have played important roles in creating early leadership opportunities for youth. For example, a widely recognized youth organization, the Boy Scouts of America, celebrated its $100^{\text {th }}$ anniversary in 2010. In the US today, nearly 4 million youth are members of the Boy and Girl Scouts. Scouting is hugely popular internationally. In Indonesia this organization exceeds 8 million; there are almost 2,7 million scouts in India and in Brazil there are over 60,000 scouts (União dos Escoteiros do Brasil, 2011; World Scout Bureau, 2008). There are many youth organizations worldwide which emphasize group activities, character development, and civic engagement. This article discusses what we know and don't know in terms of youth leadership development. Can it be taught? Should it be taught? The article proposes how youth leadership fits within gifted education.

\section{What is leadership?}

There is no one universally accepted definition of leadership. However, it is clear that leadership is persuasion; it involves influencing other people to pursue a common goal that is considered important or relevant to the group. Leadership should not be viewed as domination; at its best leadership requires others to willingly adopt the goals or mission of the group as their own. Leadership requires creating a shared vision, building trust and confidence in others, and enabling others to act toward a common goal.

Fieldler (1967) developed a contingency or 220 situational theory of leadership, proposing that three situational dimensions influence the leader's effectiveness: leader-member relations, task complexity/ structure, and the power inherent in the leadership position. Fielder's leadership model implied that leadership style is difficult to change. Hersey, Blanchard and Johnson (2007) extended Fielder's model and articulated a 3-dimensional approach for assessing leadership effectiveness. Their situational leadership model suggests that successful leaders do adjust their styles, recognizing the importance of the leader's task and relationship behaviors, and how the individual's leadership style interfaces with the task situation. They contend that successful leaders are those who can adapt their behavior to meet the demands of their own unique situation. Adaptability is central to this model (Hersey et al., 2007).

One influential popular lecturer is Warren Bennis, whose writings introduced leadership to the NorthAmerican public. Bennis (2003), a Professor at the University of Southern California, argues that leadership is not a rare skill or inborn trait; he posits that leaders are made rather than born, and that leaders need not be charismatic or brilliant individuals to be successful (Bennis \& Biederman, 1997; Bennis \& Goldsmith, 2010). Bennis does not view leadership as an innate ability. He would not conceptualize leadership talent based on high general cognitive ability (" $g$ ")-how some in the gifted field view intelligence (Gottfredson, 1997). His believes that effective leaders are able to create compelling visions, elicit trust, optimism and hope in others, and translate their visions into actionable plans.

A broader perspective of leadership was offered by Vroom and Jago (2001), emphasizing the role played by the situation or environment in leadership expression. According to their view, leadership is a process rather than a trait of a person, and the situation shapes how leaders behave. Their theory emphasizes the importance of a favorable climate for leadership emergence and the influence of certain values and support for creative ideas to flourish (Ekvall, 1996). The role of the environment is crucial (Crespo \&Wechsler, 2000). Certain leadership styles may be more facilitative in certain settings than others, or more valued according to specific goals sought by the group (Wechsler, 2009a). Leadership styles are also influenced, by gender, as women tend to be more intuitive and look for consensus in a group than men 
(Wechsler, 2009b), and these differences should be considered when trying to identify youth with high leadership potential (Pfeiffer, 2012b).

\section{Contemporary views on giftedness}

Contemporary theorists no longer view giftedness and high Intelligence Quotient (IQ) as synonymous (Borland, 2009; Foley \& Pfeiffer, 2011; Keating, 2009; Pfeiffer, 2012a; 2012b; Sternberg, Jarvin \& Grigorenko, 2011). A number of authorities now advocate for a paradigm shift, suggesting that the gifted field adopt a talent development perspective. This perspective envisions optimizing developmental pathways to expertise and accomplishment in culturally valued domains (Pfeiffer, 2012c; Subotnik, 2003; 2009).

This paradigm shift is away from viewing giftedness as the same as high $1 \mathrm{Q}$ or something permanent. The traditional view of giftedness has long posited the pre-eminence of general intellectual ability, and is perhaps best represented by the work of Gottfredson (1997; 1998). The new zeitgeist views giftedness from a developmental perspective. This new perspective views giftedness as emerging expertise, based on more than simply high general intellectual ability - rather, giftedness is conceptualized as the dynamic and synergistic interaction of multiple factors; general aptitude in dynamic relationship with a host of specific abilities, motivation, personality, and passion for a specific field or domain (Pfeiffer, 2012c). This new model views giftedness as the unfolding and transforming of potential into actual outstanding performance and accomplishments in adulthood.

Leadership can also be defined as a synthesis of intelligence, creativity and wisdom as proposed by Sternberg (2004), thus indicating that cognitive aspects interact with social and personality characteristics. Therefore, there is the need of early identification of youth with uncommon general and specific abilities, personality characteristics and attitudes associated with leadership potential, and the importance of having an adult who can serve as a mentor. From a talent development model, the goal is promoting leadership competence and even expertise among a cadre of young adolescents who exhibit early precursors of leadership (Keating, 2004; Pfeiffer, 2009).
This new and contemporary view of giftedness, particularly as applied to leadership, is based on seven principles: 1) Early identification of giftedness remains important. However, early identification should never be based exclusively on one IQ score; 2) Gifted assessment should be multifaceted and multidimensional. General intellectual ability is one important factor, but other psychological measures and constructs should be included, with due consideration of characteristics associated with leadership behavior (e.g., verbal expressive skill); 3) The measures that we use to assess giftedness must change as a child gets older, more aligned with a domain-specific focus on leadership; 4) The goal of gifted education becomes finding ways to nurture and optimize bright students' development in one or more culturally-valued fields - in this instance, the development of leadership; 5) Not all children identified at an early age as gifted will continue on a success path or trajectory toward expertise; many will not distinguish themselves in their later years as gifted leaders; 6) Many children not identified in the early years as gifted are late bloomers; and 7) Gifted programs in the schools will be successful to the extent that they focus on domain-specific curricula which matches each student's unique abilities and interests.

\section{Characteristics of effective leaders}

Several taxonomies of leadership behaviors have been proposed. Hundreds of leader behaviors have been written about in both the popular and academic leadership literatures. The following categories of behaviors and characteristics have appeared most frequently: planning; organizing; problem solving and competence; creative; innovative; motivating and inspiring; forward-looking; supportive and caring; managing conflict and team building; delegating; courageous (Pfeiffer, 2009).

A large, international study by Kouzes and Posner (2009) invited participants to comment on what they look for and admire in their leaders. Over 75,000 people participated in this investigation. The top four-ranked leadership characteristics were: honesty, forwardlooking, inspiring, and competent. These findings were corroborated in ten countries. Honesty emerged as the single most important factor; leaders are expected to 
inspire trust, be principled, know right from wrong, and have integrity. The ability to look ahead and share a vision for the future was consistently recognized as a critical leadership skill. Leaders must also be enthusiastic, energetic, optimistic, and communicate a positive view for the future. Finally, leaders must bring relevant experience and sound judgment to the task-if they hope to inspire confidence they must have a track record of success and ability to get things done. Similar characteristics for effective leaders were identified by Brazilian managers and their employees. The adjectives mostly indicated by them were honesty, comprehension, objectivity, creativity, flexibility and self confidence (Mundim \&Wechsler, 2007).

Recent breakthroughs in the study of the physiology of the brain provide fascinating insights into the neuroscience of leadership. Imaging technologies such as functional Magnetic Resonance Imaging (fMRI) and Positron Emission Tomography (PET), in conjunction with brain wave analysis technologies such as Quantitative Electroencephalography (QEEG), have helped identify important linkages between the brain and how we perceive, think, feel, and act-even with brain processing during creative problem solving (Angelakis et al., 2007; Chang et al., 2002; Collura, Thatcher, Smith, Lombos \& Stark 2009; Fink \& Neubauer, 2006; Freed, Yanagihara, Hirsch \& Mann 2009; Jaušovec, 2000; Mölle, Marshall, Wolf, Fehn \& Born, 1999; Rodriguez-Moreno \& Hirsch, 2009). These findings have implications for leadership. For example, brain research confirms that change is difficult because it provokes sensations of physiological discomfort. Trying to change any hardwired behavior requires considerable effort and will be resisted by the basal ganglia, the habit-center part of the brain that operates in large part without conscious thought.

Messages from effective leaders must be able to shift our focus from experiencing fear - what Goleman (1995) poetically describes as preventing "amygdale hijack", to drawing our attention and metabolic energy to the frontal and prefrontal regions of our brain. Leaders have the best chance of encouraging others to take risks and entertain change if their message connects with the prefrontal region of the brain, and not the more primitive and older parts of our mammalian brain, remnants of our evolutionary history.

\section{Identifying youth leadership, giftedness and creativity}

From the above brief overview, the reader can see that we know a lot about adult leadership. We know considerably less about precursors of early leadership, or how best to encourage, teach or develop leadership skills and competencies in children and youth (Matthews, 2004; Pfeiffer 2009). For example, we know very little about gender differences and early leadership potential or whether there are a set of characteristics that consistently predict to adult leadership competence (Pfeiffer, 2012c). Over 25 years ago in the US, federal definitions of giftedness included leadership ability as one type of giftedness. In Brazil, the definition of high abilities/gifted individuals also include leadership as one of their characteristics (Brasil, 2001). Thus, many gifted authorities contend that youth leadership training is important (Karnes \& Chauvin, 2000).

Some have argued that adult leadership models are not applicable to leadership among youth; others see important conceptual parallels and practical similarities between youth and adult leadership. However, youth leadership remains under-theorized and marked by few well-designed studies. For example, many gifted authorities suggest that youth leadership requires creative problem solving ability and at least moderately high intellectual ability. This view represents an "IQ threshold" point-of-view; its proponents suggest that one needs an IQ of at least 115 or 120 to be a successful leader. This idea parallels the view of some authorities in the creativity field who suggest that there is a similar IQ threshold needed for producing creative or innovative ideas or products (Kaufman, 2009). This remains a plausible but untested assumption in both the creativity and leadership fields (Pfeiffer, 2008; 2012c).

Assessing the gifted is a challenging task. The Gifted Rating Scale-School Form (GRS) was developed to help identify giftedness in children ages 6.0 to 13.11 (Pfeiffer \& Jarosewich, 2003, 2007). The GRS is based on a multidimensional model of giftedness presenting six scales, including intellectual ability, motivation and leadership. The GRS classification system indicates the likelihood that a student is gifted in leadership or one of the other gifted areas.

The Gifted Rating Scale-School Form leadership scale consists of 12 items that reflect the child's ability 
to motivate others toward a common or shared goal. Three illustrative leadership items are: demonstrates good social judgment, earns the respect and trust of others, and makes things happen. A number of international studies, including work in Brazil, indicate that the GRS is reliable and valid (Lee \& Pfeiffer, 2006; Li, Lee, Pfeiffer, Kamata \& Kumtepe, 2009; Li, Pfeiffer, Petscher, Kumtepe \& Mo, 2008; Pfeiffer \& Petscher, 2008; Pfeiffer, Petscher \& Kumtepe, 2008; Rosado, Pfeiffer \& Petscher, 2008).

The Gifted Rating Scale-School Form leadership scale has been used in youth leadership development programs to measure student growth and progress. There are other measures of youth leadership (Karnes \& Chauvin, 2000), although the GRS enjoys the most research and empirical support as a brief but accurate measure of youth leadership potential. An article in The School Psychologist provides a methodology to measure change in leadership skills using the GRS (Pfeiffer, Kumtepe \& Rosado, 2006). A pilot leadership intervention program is underway in Florida and includes the following components: leadership curriculum; exposure to a variety of leadership opportunities in the community; interaction with acknowledged adult leaders; challenging service-learning projects; and selfreflection papers. Future research will hopefully further identify reliable and robust early predictors of leadership and help generate one or more new models on early leadership potential among youth.

We do not believe that every youth can develop into a gifted leader. However, almost any adolescent, if provided appropriate opportunities and adequately motivated, can learn new, and refine existing, skills and values which are associated with effective leadership (Pfeiffer, 2001). For example, even young children can learn the nuances of social judgment and become more adept at recognizing the feelings of others. Some children, because of a combination of aptitude, personality, temperament, motivation, and passion for leadership and helping others, will develop into gifted leaders. Participation in community-based and youth leadership programs can provide unique opportunities for early exposure to leadership roles and observing important skills associated with leadership.

\section{Creativity}

Just about everyone agrees that creativity is important and valued in today's society (Sternberg et al., 2011). Chief Executive Officers (CEO) of fortune 500 companies and popular business self-help books identify creativity as a critical leadership skill (Pfeiffer \& Thompson, 2013). Creativity is valued in almost every field, in both US and Brazilian societies including medicine, the sciences, engineering, the arts, and law. It is almost impossible to think of a profession that doesn't hold in the high regard innovation, ingenuity, and imagination. The importance of innovation to Brazilian society was recognized by federal law (Brasil, 2004).

And yet in today's schools we continue to place too much emphasis on a standardized curriculum, rote learning of facts, and memorization. A great number of schools today still focus considerable time and resources on the learning and recall of information. We ask our students to learn to define, describe, identify, know, label, match, name, recall, and recognize information, when viewed from a well-known taxonomy of learning objectives (Bloom, 1956). Schools demand less of students in terms of higher-level cognitive skills, including understanding, applying, analyzing, evaluating and creating. It is difficult to understand how any country can pursue high creativity and innovation, and be globally competitive, if their schools don't emphasize creative thinking (Wechsler, 2011).

What exactly is creativity? Creativity reflects a particular way in which individuals think, solve problems or produce art or products in a given field. To others, creativity represents certain people who are endowed with certain cognitive and personality characteristics which make them more likely to be innovative. A number of authors distinguish between four different perspectives in defining what we mean by creativity: creativity in terms of how creative a product is, a particular process or way of thinking about things, particular persons with a lot of creative ability, and aspects of the environment that either facilitate or impede the expression of creativity (Kaufman, 2009; Rhodes, 1962). Creativity can be understood as a multidimensional concept, involving a combination of cognitive processes, personality characteristics, and environmental variables (Wechsler, 2008).

Classrooms vary in terms of the degree to which they are conducive or favorable to the development of creativity, including creative leadership. Creativity is one 
important component and expression of gifted expertise (Pfeiffer, 2012b). As the student progresses through schooling, he gains increased factual, conceptual and procedural knowledge, and gains increasing experience and competence in one or more fields. As part of this developmental progression, the student begins to demonstrate increased domain-specific creativity. This is consistent with what is known in the creativity field as domain specificity (Baer, 1998, 2011). Individuals demonstrate significant individual differences in terms of their potential for and capacity to be creative, as well as their potential or capacity to be distinguished leaders.

Most of the research with high ability students has been at a crossroads between the Big C (expressions of creativity among high ability students on a trajectory toward outstanding - and innovative -, leadership performance) and the Little ( creativity of everyday life (Kozbelt, Beghetto \& Runco, 2010; Richards, 2007). Children and adolescents, even those who test at very high levels of intellectual ability vary in terms of their capacity for creative expression. This does not mean that kids are either creative or not creative, as born either creative or uncreative (Plucker, Beghetto \& Dow, 2004). However, individuals demonstrate significant individual differences in terms of their potential for and capacity to be creative and their potential or capacity to be distinguished leaders. This is based on the synergetic interaction of genetic, intellectual, temperamental, personality, attitudinal, and environmental factors. As we have said, classrooms also vary in terms of the degree to which they are conducive or favorable to the development of creativity, including creative leadership. The flow experience, which is the intensive concentration in a task due to great motivation has been emphasized as one important condition to develop creative learning (Csikzentmihalyi, 1990).

To be creative, an idea or work must be original, novel and distinctive. And to be creative, an idea or work must not only be original, novel and distinctive, but also judged to be relevant, appropriate, useful, beneficial, helpful, valuable, and/or aesthetically pleasing (Plucker et al., 2004; Pfeiffer, 2012a; Sternberg \& Kaufman, 2010). What remains unclear - and still un-researched at the moment -, is whether there is a causal relationship between giftedness, early leadership potential, and

224 creativity. One would suspect that these three constructs are related, but we will need to be patient and await research studies that investigate this intriguing hypothesis.

Schools represent the existing values in families and the community. Creative students are often seen as non-conformers or questioning the status quo. It is not difficult to understand why creativity is not encouraged; on the contrary, it often is suppressed in the elementary grades. In both the US and Brazil the level of creativity decreases over the course of schooling (Nakano \& Wechsler, 2006; Torrance, 1979; Wechsler \& Richmond, 1982). As mentioned earlier, the emphasis on rote learning of facts and memorization does not encourage divergent thinking and intellectual risk taking. Creative thinking styles in the classroom are often discouraged (Fleith, 2006; Siqueira \&Wechsler, 2004).

In Brazil, federal law defines and regulates the pedagogy and guidance provided to students with special needs, including gifted and high ability students (Brasil, 2011). According to this law, schools are required to provide opportunities for talent identification and development, with challenging tasks in the regular or special curricula for gifted students. However, there is a considerable gap between this "desire for excellence" and actual practice. Teachers often lack the preparation, motivation or resources to provide differential learning opportunities (Fleith, 2008; Wechsler \& Souza, 2011). There is an urgent need to better prepare teachers to identify and develop leadership talent (Alencar, 2000; Wechsler \&Nakano, 2011).

We view creativity as one component of the unfolding of talent in any culturally-valued field or domain, including leadership. The unfolding and nurturance of creativity, as part of gaining expertise and even distinguished status as a leader, recognizes eight components. First, it is still debated if a minimal threshold of general intellectual ability is necessary for students to reach a level or expertise as a leader. Although a high level of intellectual ability is necessary for creativity in certain academic fields, it is not sufficient as other characteristics, such as curiosity and motivation, play an important role for success in these areas (Benbow \& Lubinsky, 1996; Wai, Lubinski \& Benbow, 2005). Anecdotal reports suggest that a high-average $I Q$ is a minimum for successful leadership, and for some fields, such as engineering and mathematics, a considerably higher 
IQ threshold is necessary. There is, however, a lack of agreement among international researchers about a minimal threshold for creative production (Runco, 2007; Wechsler, Nunes, Schelini, Ferreira \& Pereira, 2010). IQ is never enough to reach a level of success and expertise as an effective leader. Of course, the same can be said in almost all fields. Specific abilities, well-honed skills, social intelligence, and domain-specific competencies are critical if one hopes to move beyond competence toward expertise in any domain. A model is presented in Figure 1 which incorporates ideas proposed by a number of leading authorities in the gifted and talent development fields, including Bloom (1985), Gagné (2005) and Subotnik (2003).

The model depicts how creativity is conceptualized as one component that develops in a later stage of the unfolding of talent. According to Pfeiffer (2012c), creativity is located near the apex of the talent development model, consistent with a domain-specific theory of creativity, research in the field of expertise, and considerable experience of the authors working closely with high ability children and youth in the US and Brazil. Creativity and innovation are the result of a solid foundational base of factual, conceptual and procedural knowledge (Bloom, 1956), and considerable experience in leadership activities. In other words, bright students require a variety of structured and real-world learning experiences before we can expect that they will display the imagination, originality, and

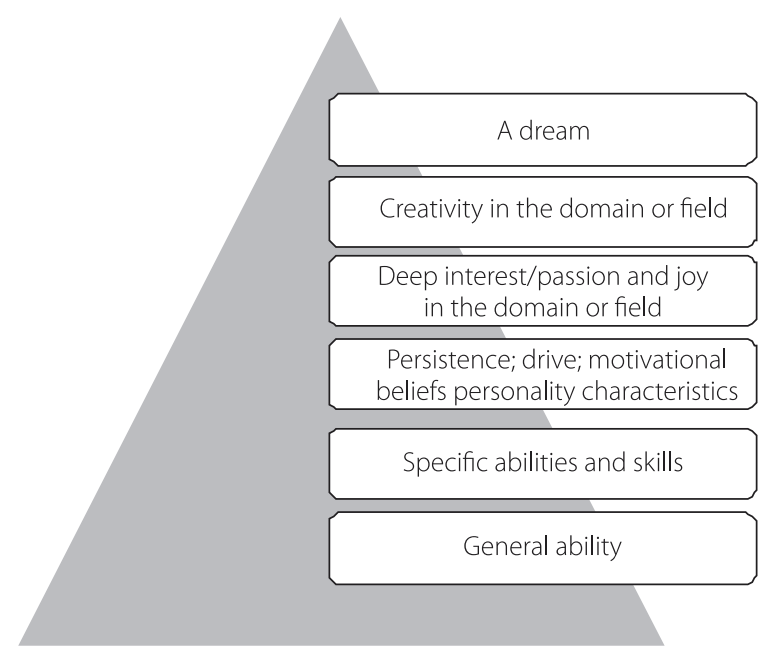

Figure 1. Factors critical to leadership development (Pfeiffer, 2012c). resourcefulness - the hallmark of creative leadership. Third, the model depicts stages along the talent development trajectory that are influenced by personenvironment interactions and marked by changes-really transformations-in thinking, attitude, motivation, and even personality. The student who is competent in chess, debate, solving mathematical problems or in being a leader is very different from the youngster who has progressed on to a level of expertise in chess, debate, solving mathematical problems, or being a leader. One expects to begin to see creative thinking and creative performance as the youngster moves from a level of competence to an elite or expert level in any field, including leadership.

Fourth, if students of uncanny ability continue to successfully progress along the talent development trajectory to expertise and even eminent status as a leader, the following factors become increasingly important: specific interpersonal skills, drive, persistence, self-confidence, passion for leading others, facilitative motivational beliefs, a willingness to listen and learn from others, and the dream of becoming a leader. Fifth, sustained interest in pursuing one's dream of becoming a leader and a commitment to excellence are critical to reach the highest levels; creativity is much easier to nurture and encourage if the student is passionate about becoming a leader and has a "rage"to learn (Piirto, 2008; Winner, 1996). Lionel Messi, as many readers may know, is an internationally recognized futbol player who plays for the world-renowned team, Futbol Club Barcelona. $\mathrm{He}$ is considered one of the most creative players in the world. The celebrated Uruguayan novelist Eduardo Galeano recently wrote an essay on Messi, including this poignant comment, "No one plays with as much joy as Messi does... . He plays like a child enjoying the pasture, playing for the pleasure of playing, not the duty of winning" (Longman, 2011, p.6). Sixth, a substantial investment of time is necessary to reach the highest levels as a leader (Ericsson, Krampe \&Tesch-Romer, 1993).

Seventh, only a select number of individuals reach the highest levels of eminent status in any domain or field, including leadership. There is always going to be a small number who reach the pinnacle and are recognized as uniquely creative leaders. This is certainly true for the creative individual, as well; only a small number of students with uncanny potential at an early 
age reach the Big C level of creativity-irrespective of whether we are considering creative leaders, scientists, artists, teachers, athletes, surgeons, architects, or computer programmers.

Finally, the model consists of four distinct stages with transitional or sub-stages. Each stage is marked by transformations (Pfeiffer, 2012c). First, the child is exposed to knowledge, skills and experience in a specific field or domain-such as leadership, hopefully presented in an enjoyable and reinforcing fashion; second, over time the individual reaches a recognized threshold where they attain competence in the domain; third, the individual continues to gain further experience, guidance and instruction to the point where they reach a level of mastery or expertise in the domain-at this point, we observe clear evidence of domain-specific creativity; finally, further development, experience, and refinement of one's expertise can lead a very select few to a pre-eminent level of accomplishment as a leader. Only the most promising are likely to attain a level of eminence as a creative leader. This final stage is marked by clear evidence of Big C creativity, which in fact is one of the defining features of eminence.

This model is consistent with Bloom's (1956) taxonomy, in which creativity unfolds only after the more foundational cognitive operations of remembering, understanding, applying, analyzing, and evaluating-be it factual knowledge, conceptual knowledge, procedural knowledge or meta-cognitive knowledge-are first solidified. Although one may not see creativity expressed in the first two stages of this model, the type of processes required at the upper stages are conducive to creative expression. Personality characteristics such as motivation, persistence, deep interest, passion and joy tend to be all present in creative personalities, as has been observed in international research (Kaufman, Plucker \& Baer, 2008; Siqueira \& Wechsler, 2009).

\section{Final Considerations}

The gifted field lacks even one large scale study that has followed a large cohort of high ability children examining early precursors of leadership. There is no study that has followed over time a large community of gifted children identified at an early age with precocious leadership skills or attitudes.

We know a lot about leadership from the adult leadership literature. We know, for example, that almost all people, irrespective of whether they are from Brazil or the US consider honesty, forward-looking, inspiring, and competence as critical characteristics of effective adult leaders. Honesty emerges as the single most important quality; leaders are expected to inspire trust, demonstrate unwavering integrity, and know right from wrong. The ability to look ahead and the ability to create a shared a vision for-the-future are both important leadership skills. Effective leaders should be enthusiastic, energetic, and optimistic, what Pfeiffer (2012b) labels as "heart strengths."

Effective leaders must bring relevant experience and have sound judgment. And effective leaders must be innovative and creative, particularly at times of challenge and crisis. These are valuable insights to help guide researchers interested in understanding more about early precursors of leadership. And these are valuable insights to help guide educators interested in designing effective youth leadership development programs in the schools and community. It is obvious that if we hope for our youth to develop into effective and ethical leaders as adults, we need to expose them to readings, discussion, and real-life learning opportunities that introduce topics such as interpersonal decisionmaking, social dynamics, conflict resolution, group behavior, goal setting, and integrity and trustworthiness (Pfeiffer, 2012c).

The proposed model offers a long-range trajectory for developing children's intellectual and creative potential that encourages a future cadre of talented leaders. In order for societies-both large and small-across our planet to grow, thrive, and peacefully cooperate, educators and policy makers must commit resources to leadership development.

\section{References}

Alencar, E. M. L. S. (2000). O papel do professor facilitador e do professor inibidor segundo estudantes de pós-graduação. Boletim da Academia Paulista de Psicologia, 19(1), 84-94.

Angelakis, E., Stathopoulou, S., Frymiare, J. L., Green, L., Lubar, J. F., \& Kounious, J. (2007). EEG neurofeedback: A 
brief overview and an example of peak alpha frequency training for cognitive enhancement in the elderly. The Clinical Neuropsychologist, 21(1), 110-129.

Baer, J. (1998). The case for domain specificity in creativity. Creativity Research Journal, 11(2), 173-177.

Baer, J. (2011). Why grand theories of creativity distort, distract, and disappoint. The International Journal of Creativity and Problem Solving, 21(1), 73-100.

Benbow, C. P., \& Lubinski, D. (1996). (Eds.), Intellectual talent: Psychometric and social issues. Baltimore, MD: Johns Hopkins University Press.

Bennis, W. (2003). On becoming a leader. Cambridge, MA: Perseus Pub.

Bennis, W., \& Biederman, P. W. (1997). Organizing genius: The secrets of creative collaboration. Cambridge, MA: Perseus Books.

Bennis, W., \& Goldsmith, J. (2010). Learning to lead. New York: Basic Books.

Bloom, B. S. (1956). Taxonomy of educational objectives: Handbookl: The cognitive domain. New York: David McKay.

Bloom, B. S. (1985). Developing talent in young people. New York: Ballantine Books.

Borland, J. H. (2009). Myth 2: The gifted constitute 3\% to 5\% of the population. Moreover, giftedness equals high IQ, which is a stable measure of aptitude. Spinal tap psychometrics in gifted education. Gifted Child Quarterly, 53(4), 236-238.

Brasil. Camara dos Deputados. (2004). Lei no 10.973, de 2 de dezembro de 2004. Recuperado em dezembro 2, 2004, disponível em <http://www2.camara.gov.br/legin/fed/ lei/2004/lei-10973-2-dezembro-2004-534975-publicacao original-21531-pl.html>

Brasil. Conselho Nacional de Educação. (2001). Resolução no 2/2001. Diretrizes nacionais da educação especial para a educação básica. Recuperado em dezembro 5, 2012, disponível em <http://portal.mec.gov.br/seesp/arquivos/ $\mathrm{pdf} /$ diretrizes.pdf $>$.

Brasil. Conselho Nacional de Educação. (2011). Decreto no 7.611, de 17 de novembro de 2011. Recuperado em dezembro 5, 2012, disponível em <http://www2.camara.gov.br/ legin/fed/decret/2011/decreto-7611-17-novembro2011-611788-publicacaooriginal-134270-pe.html>.

Chang, L., Emst, T., Speck, O., Patel, H., DeSilva, M., LeonidoYee, M., et al. (2002). Perfusion MRI and computerized test abnormalities in abstinent methamphetamine users. Psychiatry Research Neuroimaging, 114(2), 65-79.

Collura, T. F., Thatcher, R. W., Smith, M. L., Lambos, W. A., \& Stark, C. R. (2009). EEG biofeedback training using z-scores and a normative database. In W. Evans, T. Budzynski, H. Budzynski \& A. Arbanal (Eds.), Introduction to geeg and Neurofeedback: Advanced theory and applications ( $2^{\text {th }}$ ed.). New York: Elsevier.

Crespo, M. L., \& Wechsler, S. (2000). Clima criativo: um diagnóstico para a inovação nas organizações educacionais e empresariais Psicodebate: Psicología, Cultura y Sociedad, 1(1), 53-61.
Csikzentmihalyi, M. (1990). Flow: The psychology of optimal experience. New York: Harper \& Row Publishers.

Ekvall, G. (1996). Organizational climate for creativity and innovation. European Journal of Work and Organizational Psychology, 5(1), 105-123

Ericsson, K., Krampe, R. \& Tesch-Romer, C. (1993). The role of deliberate practice in the acquisition of expert performance. Psychological Review, 100(3), 363-406.

Fielder, F. (1967). A theory of leadership effectiveness. New York: Bantam Books.

Fink, A., \& Neubauer, A. C. (2006). EEG alpha oscillations during the performance of verbal creativity tasks: Differential effects of sex and verbal intelligence. International Journal of Psychophysiology, 62(1), 46-53.

Fleith, D. S. (2006). Percepção de alunos de ensino fundamental quanto ao clima de sala de aula para a criatividade. Psicologia em Estudo, 11 (3), 513-521.

Fleith, D. S. (2008). Características personológicas e fatores ambientais relacionados a criatividade no ensino fundamental. Avaliação Psicológica, 7(1), 35-44.

Foley, N. M., \& Pfeiffer, S. I. (2011). High ability students: New ways to conceptualize giftedness and provide psychological services in the schools. Journal of Applied School Psychology, 27(4), 293-305.

Freed, P., Yanagihara, T., Hirsch, J., \& Mann, J. (2009). Neural mechanisms of grief regulation. Biological Psychiatry, 66(1), 33-40.

Gagné, F. (2005). From gifts to talents: The DMGT as a developmental model. In R. J. Sternberg \& J. E. Davidson (Eds.), Conceptions of giftedness (2 ${ }^{\text {nd }}$ ed., pp.98-120). Cambridge: Cambridge University Press.

Goleman, D. (1995). Emotional intelligence. New York: Bantam Books.

Gottfredson, L. S. (1997). Why g matters. Intelligence, 24(1), 79-132.

Gottfredson, L. S. (1998). The general intelligence factor. Scientific American, 9(4), 24-30.

Hersey, P., Blanchard, K. H., \& Johnson, D. E. (2007). Management and organizational behavior:Leading human resources. New York: Prentice Hall.

Jaušovec, N. (2000). Differences in cognitive processes between gifted, intelligence, creative, and average individuals while solving complex problems: An EEG study. Intelligence, 28(3), 213-237.

Karnes, F. A., \& Chauvin, J. C. (2000). Leadership development program. Scottsdale, AZ: Gifted Psychology Press.

Kaufman, J. C. (2009). Creativity 101. New York: Springer.

Kaufman, J. C., Plucker, J. A., \& Baer, J. (2008). Essentials of creativity assessment. New York: John Wiley \& Sons.

Keating, D. P. (2004). Cognitive and brain development. In R. Lerner \& L. Sternberg (Eds.), Handbook of adolescent psychology (pp.45-84). New York: John Wiley \& Sons.

Keating, D. P. (2009). Developmental science and giftedness: An integrated life-span framework. In F. D. Horowitz, R. 
F. Subotnik \& D. J. Matthews. (Eds.), The development of giftedness and talent across the life Span (pp.189-208). Washington, DC: American Psychological Association.

Kouzes, J., \& Porner, R. (2009). The leadership challenge. Retrived January 24, 2009, from <http://www. leadershipchallenge.com/WilleyCDA>.

Kozbelt, A., Beghetto, R. A., \& Runco, M. A. (2010). Theories of creativity. In J. C. Kaufman \& R. J. Sternberg (Eds.), The Cambridge handbook of creativity (pp.20-47). New York: Cambridge University Press.

Lee, D., \& Pfeiffer, S. I. (2006). The reliability and validity of a Korean translated version of the gifted rating scales. Journal of Psychoeducational Assessment, 24, 210-224.

Li, H., Lee, D., Pfeiffer, S. I., Kamata, A., \& Kumtepe, A. T. (2009). Measurement invariance of the gifted rating scales-school form across five cultural groups. School Psychology Quarterly, 24(3), 186-198.

Li, H., Pfeiffer, S. I., Petscher, Y., Kumtepe, A., \& Mo, G. (2008). Validation of the GRS-school form in China. Gifted Child Quarterly, 52(2), 160-169.

Longman, J. (2011, May 22). Boy genius. Times Sports Sunday, pp.1, 6-7.

Matthews, M. S. (2004). Leadership education for gifted and talented youth: A review of the literature. Journal for the Education of the Gifted, 28(1), 77-113.

Mölle, M., Marshall, L., Wolf, B., Fehn, H. L., \& Born, J. (1999). EEG complexity and performance measures of creative thinking. Psychophysiology, 36(1), 95-104.

Mundim, M. C., \& Wechsler, S. M. (2007). Estilos de pensar em gerentes organizacionais. Boletim de Psicologia, 5(57), 15-32.

Nakano, T. C., \& Wechsler, S. M. (2006). O percurso da criatividade do ensino medio ao ensino superior. Boletim de Psicologia, 5(56), 205-219.

Pfeiffer, S. I. (2001). Emotional intelligence: Popular but elusive construct. Roeper Review, 23(3), 138-142.

Pfeiffer, S. I. (Ed.). (2008). Handbook of giftedness. New York: Springer.

Pfeiffer, S. I. (2009). Leadership. In B. Kerr (Ed.), Encyclopedia of giftedness, creativity, and talent (pp.520-523). Thousand Oaks, CA: Sage Publishers.

Pfeiffer, S. I. (2012a). Current perspectives on the identification and assessment of gifted students. Journal of Psychoeducational Assessment, 30(1), 3-9.

Pfeiffer, S. I. (2012b). Lessons learned from working with high-ability students. Gifted Education International. Advance online publication. doi: 10.1177/0261429 412440653 .

Pfeiffer, S. I. (2012c). Serving the gifted: Evidence-based clinical and psycho-educational practice. New York: Routledge.

Pfeiffer, S. I., \& Jarosewich, T. (2003). The gifted rating scales. San Antonio: Pearson Assessment.

Pfeiffer, S. I., \& Jarosewich, T. (2007). The gifted rating 228 scales-school form: An analysis of the standardization sample based on age, gender, race and diagnostic efficiency. Gifted Child Quarterly, 51(1), 39-50.

Pfeiffer, S. I., Kumtepe, A., \& Rosado, J. (2006). Gifted identification: Measuring change in a student's profile of abilities using the GRS. The School Psychologist, 60(3), 106-111.

Pfeiffer, S. I., \& Petscher, Y. (2008). Identifying young gifted children using the gifted rating scales-preschool/ kindergarten form. Gifted Child Quarterly, 52(1), 19-29.

Pfeiffer, S. I., Petscher, Y., \& Kumtepe, A. (2008). The GRS-school form: A validation study based on age, gender and race. Roeper Review, 30(2), 140-146.

Pfeiffer, S. I., \& Thompson, T. L. (2013). Creativity from a talent development perspective: How can it be cultivated in the schools. In K. Kim, J. C. Kaufman, J. Baer \& B. Sriramen (Eds.), Creatively gifted students are not like other gifted students: Research, theory, and practice (pp.231-255). Rotterdam: Sense Publishers.

Piirto, J. (2008). Giftedness in nonacademic domains. In S. I. Pfeiffer (Ed.), Handbook of giftedness in children (pp.367-386). New York: Springer.

Plucker, J. A., Beghetto, R. A., \& Dow, G. T. (2004). Why isn't creativity more important to educational psychologists? Potentials, pitfalls, and future directions in creativity research. Educational Psychologist, 39(2), 83-96.

Richards, R. (2007). Everyday creativity: Our hidden potential. In R. Richards (Ed.), Everyday creativity and new views of human nature: Psychological, social, and spiritual perspectives (pp.25-53). Washington, DC: APA.

Rodriguez-Moreno, D., \& Hirsch, J. (2009). The dynamics of deductive reasoning: An fMRI investigation, Neuropsychologia, 47(4), 949-961.

Rhodes, M. (1962). An analysis of creativity. Phi Delta Kappan, 42, 305-311.

Rosado, J., Pfeiffer, S. I., \& Petscher, Y. (2008). The reliability and validity of a Spanish translated version of the gifted rating scales. Gifted \& Talented International Journal, 23(1), 105-115.

Runco, M. A. (2007). Creativity: Theories, themes, research and practice. London: Elsevier Academic Press.

Siqueira, L. G. G., \& Wechsler, S. M. (2004). Estilos de pensar e criar e desempenho escolar. Revista Iberoamericana de Diagnóstico y Evaluación Psicológica, 18(1), 15-22.

Siqueira, L. G. G., \& Wechsler, S. M. (2009). Motivação para aprendizagem escolar e estilos criativos. Educação Tematica Digital, 10(Esp.), 124-146.

Sternberg, R. J. (2004). WICS: A model of educational leaderhip. The Educational Forum, 68(2), 108-114.

Sternberg, R. J., Jarvin, L., \& Grigorenko. E. L. (2011). Explorations in giftedness. New York: Cambridge University Press.

Sternberg, R. J., \& Kaufman, J. C. (2010). Constraints on creativity. In J. C. Kaufman \& R. J. Sternberg (Eds.), The Cambridge handbook of creativity (pp. 467-482). New York: Cambridge University Press. 
Subotnik, R. F. (2003). A developmental view of giftedness: From being to doing. Roeper Review, 26(1), 14-15.

Subotnik, R. F. (2009). Developmental transitions in giftedness and talent: Adolescence into adulthood. In F. D. Horowitz, R. F. Subotnik \& D. J. Matthews (Eds.), The development of giftedness and talent across the life span (pp.155-170). Washington, DC: American Psychological Association.

Torrance, E. P. (1979). The search for satori and creativity. New York: Creative Education Foundation.

União dos Escoteiros do Brasil. (2011). Escoteiros do Brasil: a vida ao ar livre. Curitiba: Autor. Recuperado em dezembro 5, 2012, disponível em <http://www.escoteiros.org.br/ institucional/>.

Vroom, V., \& Jago, A. (2001). The role of situation in leadership. American Psychologist, 62(1), 17-24.

Wai, J., Lubinski, D., \& Benbow, C. (2005). Creativity and occupational accomplishments among intellectually precocious youths: An age 13 to age 33 longitudinal study. Journal of Educational Psychology, 97(3), 484-492.

Wechsler, S. M. (2008). Criatividade: descobrindo eencorajando (3a ed.). Campinas: PUC-Campinas.

Wechsler, S. M. (2009a.). Estilos de pensar e criar: implicações para a liderança. In Z. G. Giglio, S. M. Wechsler \& D. Bragotto (Eds.), Da criatividade à inovação (pp.39-60). São Paulo: Papirus.
Wechsler, S. M. (2009b). Age and gender impact on thinking and creating styles. European Journal of Psychology and Education, 2(1), 37-48.

Wechsler, S. M. (2011). Criatividade e inovação no contexto brasileiro. I Conferência Internacional de Criatividade e Inovação. Recuperado em dezembro 5, 2012, disponível em <http://www.criabrasilis.org.br/arquivos/pdfs/122_ anais_trabalhos_completos.pdf $>$.

Wechsler, S. M., \& Nakano, T. C. (2011). Criatividade na universidade: uma perspectiva internacional. São Paulo: Vetor.

Wechsler, S. M., Nunes, M. F. O., Schelini, P. W., Ferreira, A. A., \& Pereira, D. A. P. (2010). Criatividade e inteligência: analisando semelhancas e discrepancias no desenvolvimento. Estudos de Psicologia (Natal), 15(3), 243-250.

Wechsler, S. M., \& Souza, V. L. T. (2011). Criatividade e aprendizagem: caminhos e descobertas em perspectiva internacional. São Paulo: Papirus.

Wechsler, S. M., \& Richmond, B. (1982). Creative strengths of Brazilian and American children. Interamerican Journal of Psychology, 16(1), 27-32.

Winner, E. (1996). Gifted children. New York: Basic Books.

World Scout Boreau. (2008). Annexes: Triennial report 2005-2008. Geneva: Author.

Received on: 16/12/2011

Final version on: 19/6/2012

Approved on: 6/7/2012 
